restoration of Peturrson's Ravine, spring and fall bird counts, submission of bird observations for The Birds of Saskatoon (published 1996) to studies of lakes and marshes for the Canadian Wildlife Service.
Rev. Annabelle Wallace, who knew Ron for many years, says of him: "He lived simply so he could be generous. He gave of himself constantly, yet he served quietly. Happy, learned, humorous, proud of his heritage, he was a joy to be with."

-Written By Frank Roy

\title{
BAND-TAILED PIGEON IN SASKATOON, SK
}

On June 29, 2011 my husband was in his living room chair when he looked up to the back yard bird feeders and said "There's a hawk sitting on the feeder hanger". I quickly went to the window and said "Not a hawk, but a pigeon". Because it looked different I quickly got the camera and took pictures. When we compared the pictures to our bird books we identified the bird as a Band-tailed Pigeon and realized this bird was not supposed to be in our area.

The Pigeon sat on the arms of the feeders and then flew to a tree in the yard West of us and appeared to be eating. I quietly went into the back yard to see if I could get any other pictures. It flew back to the Shurbert Chokecherry in the SE corner of our yard and when I moved and walked toward it it flew away. We did not see it again.

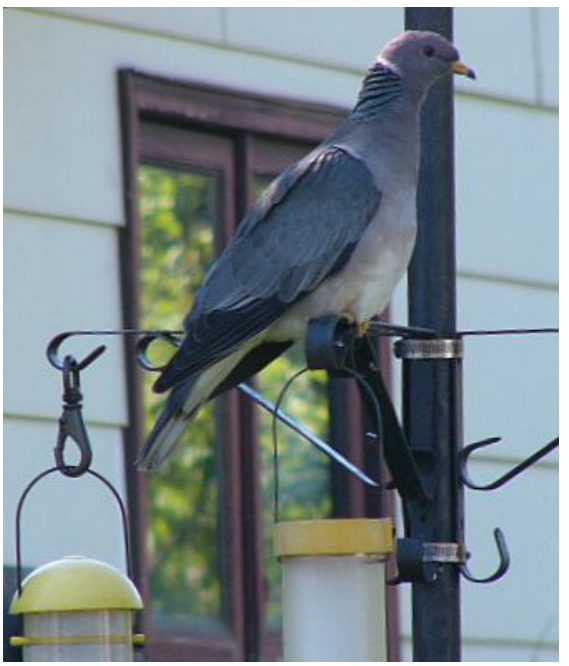

- Trish Santo, 144 Delaronde Rd, Saskatoon Sk S7J 3Y4 <tsanto@sasktel.net>

\section{ROCK PTARMIGAN - A NEW BIRD FOR ALBERTA}

Kevin Kuipers ${ }^{1}$, Natalie Kuipers, Peter Storer ${ }^{1} P O$ Box 90, Garden River, AB, TOH 4G0, Email: <kpkuipers@gmail.com>

On December 18 2011, we participated in the first Garden River Christmas Bird Count (CBC). After being in the province for only three and a half months, and having yet to experience a winter in the 'North', our familiarity with winter Alberta species was mostly limited to our printed resources. Nonetheless we had a very good idea of what we may run into due to range maps. Furthermore, due to the remoteness of Garden River, there was a sense of potential discovery. If a rare winter resident had yet to be identified in the province, surely this was the location it was hiding.

For the $\mathrm{CBC}$, the temperature was $-24^{\circ} \mathrm{C}$ and sunny, with some bird activity in the Jack Pine stands. While driving eastbound $15 \mathrm{~km}$ west of Garden River, we encountered a Ptarmigan on the road. Peter was quick to note he almost 
drove over it, as it camouflaged with the surrounding snow perfectly. The bird quickly flew to the adjacent forest, but boomeranged back onto the road in front of the vehicle.

Upon getting out of the vehicle, we immediately noted a black line running from the beak just past the eye, a feature I knew to be diagnostic. The question was, diagnostic of which species? A quick flip of a few pages produced the answer; a Rock Ptarmigan Lagopus mutus. I was aware this was a good find, but was under the impression that it was an irregular visitor to northern Alberta. I was wrong, and wouldn't find that out for a couple of days. Luckily Peter had brought along his digital SLR camera, and snapped a few pictures of it as it cautiously walked away from us. After a few more minutes of examining its feathery legs, we continued on our way.

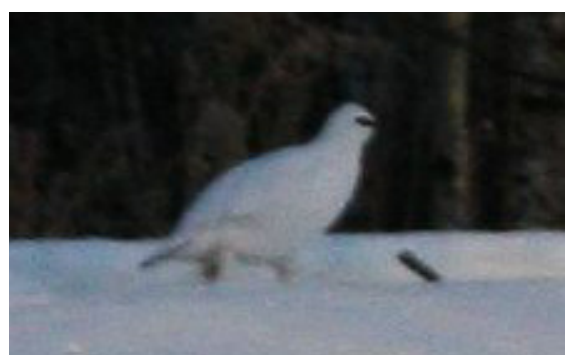

Figure 1 - Photograph of Rock Ptarmigan in Alberta

After finishing the count, I did some research and excitedly discovered that the Rock Ptarmigan was a new bird in Alberta for the CBC. The surprises did not cease, however, and after reading through Alberta's Official Bird List, ${ }^{1}$ found that the Rock Ptarmigan was absent from the list. Thank goodness for the photos. A few hours of general excitement ensued, intertwined with emails to various authoritative Alberta birding figures.

The Rock Ptarmigan was formerly considered "hypothetical" in Alberta, i.e., reported but without full substantiating evidence such as a photograph or specimen $^{2}$ (Figure 1).

However, it is a rare winter visitor to the Uranium City area of extreme NW Saskatchewan, with six records of single birds or coveys between 1957 and 1975. There have been few observers in that region since then. ${ }^{3}$

In winters past, it could be found in varying numbers (and frequency) on the Churchill Christmas Bird Count in Manitoba, having been reported on 16 of $21 \mathrm{CBCs}$, with hundreds or even thousands present until late March and early April during an irruption in $1998 .{ }^{4}$ It has also been documented further inland, as far as $280 \mathrm{~km}$ from the Hudson Bay coast. $^{5}$

As my wife and I will be living in Northern Alberta for a few years to come, our residence in such a remote location may prove to be very beneficial to further bird population research. We will continue to monitor sightings, documenting as many as possible, and ensuring that each Rock Ptarmigan encountered will be reported.

1. http://www.royalalbertamuseum.ca/ natural/birds/birdlist/taxon.htm

2. Salt WR, Salt JR (1976) The birds of Alberta, Hurtig Publishers, Edmonton, AB.

3. Smith AR (1996) Atlas of Saskatchewan birds, Saskatchewan Natural History Society Special Publication No. 22, p. 124.

4. Manitoba Avian Research Committee (2003) The birds of Manitoba, Manitoba Naturalists Society, Winnipeg, MB, pp. 152-153.

5. Larche RA, Sealy SG (1977) Inland records of the rock ptarmigan in Manitoba, Blue Jay 35:99-100. 